\title{
The Prime Rate and the Cost of Funds: Is the Prime Too High?
}

\section{R. W. HAFER}

B

ANK lending rates recently have received considerable attention in the popular press. ${ }^{1}$ There appears to be widespread opinion that the rates charged by banks exceed their cost of funds by an abnormal amount. The purpose of this article is to assess whether banks' lending rates during the past few months have been "too high" relative to other market rates. Because the prime rate generally is viewed as a benchmark lending rate for banks, the analysis focuses on the recent behavior of this rate relative to other market interest rates.

\section{TH FUNOS}

The prime rate quoted in the press and discussed by the public commonly is considered to be the interest rate charged to a bank's most credit-worthy corporate customers for short-term loans. The prime rate is not, however, the rate charged to each and every corporate borrower; each loan and prospective borrower have their own characteristics that may necessitate different lending rates. ${ }^{2}$ For example, the loan rate charged to a specific customer reflects that customer's credit worthiness, previous relationship with the bank, the maturity of the loan, the nonfee services provided by the bank in maintaining the loan, the use of fixed or flexible maturities and rates, and other factors.

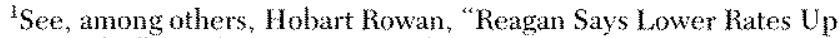
to Banks," Washington Post, February 24, 1983; Teresa Carson, "Reagan Latest to Criticize Bank Rates," American Banker, February 24, 1983; "More Pressure on Loan Rates," New York Times, February 27, 1983; and Leah R. Young. "Charges Against Banks on Rates "Unfounded," New York Joumal of Commerce, March 18 , 1983. For ar interesting conparison of today's arguments. see Leonard Silk, "The Mystery of High Rates," New York Times, March 1"i, 1982 .

"The following discussion draws on Gerald C. Fischer, "The Myth and the Reality of the Prime Rate,"Journal of Commercial Bank
} Lending (July 1982), pp. 16-26.
Before the $1970 \mathrm{~s}$, the prime rate was relatively slow to adjust to market conditions. For instance, between 1929 and 1969, the prime rate changed only 40 times, an average of once per year and less often than market interest rates. In contrast, since 1970 the rate has changed an average of about 13 times per year.

This shift in the prime rate's more frequent adjustment to credit market conditions occurred in 1972 when the First National City Bank of New York, known today as Citibank, announced that its prime rate would be pegged to the 90 -day commercial paper rate. This change was important because it directly linked the prime rate to current credit market conditions. Furthermore, as the competition for loanable funds and the cost of liability management have increased with the advent of numerous financial innovations, banks have become more sensitive to interest rate changes when establishing their lending rates. ${ }^{3}$

The increased sensitivity of the prime rate to market rates has accompanied certain changes in the credit market. The rapidly expanding use of the commercial paper market as an alternative to bank funding is one example. Another is the increased competition coming from money market funds which has increased the need for flexibility in the income stream from the bank's loan portfolio. More recently, the volatility of market rates has contributed to more frequent changes in the prime rate. Because of this sensitivity, there should be a close empirical relationship between the bank's cost of funds and the prime rate. If such a relationship exists, it can be used to assess the current level of the prime rate with respect to other interest rates that reflect the prevailing cost of funds facing banks.

${ }^{3}$ Ibid. See also, Michael A. Goldberg, The Pricing of the Prime Rate," Journal of Banking and Finance (July 1982), pp. $277-96$. 
To investigate this issue, two interest rates are used. One important source of loanable funds is the $90 \mathrm{day}$ certificate of deposit (CD) market; as such, the 90-day CD rate is a useful measure of a bank's cost of funds. Although recent financial innovations may have lessened the once primary position held by the CD market, it remains a key source of funds, ${ }^{4}$ The federal funds rate - the rate charged for overnight funds - also is a useful measure of the bank's cost of funds. It not only measures the bank's cost of short-term funds, but also is watched by credit market participants as a guide to Federal Reserve actions. In other words, it is viewed as an indicator of whether current credit demands are being matched by the reserves supplied to the banking system.

\section{The Evidence}

Chart 1 plots the prime rate, the 90-day CD rate and the federal funds rate for the period September 1980 to December $1982 .^{5}$ As illustrated, the prime rate tends to follow movements in the other interest rates, albeit with a slight lag. This tendency reflects the previously mentioned sensitivity of the prime rate to other market rates - that is, the effect of current and past costs of the bank's managed liabilities.

The data in chart 1 can be translated into a regression relationship to provide a more rigorous assessment of

${ }^{t}$ For example, as of year-end 1981 , negotiable CDs at large weekly reporting banks with assets of $\$ 750$ million or more totaled $\$ 137,400$ million. Consumer and industrial loans (C\&I) were $\$ 195,499$ million. Thus, the ratio of CDs to C\&N loans was 0.7 . In December 1982, however, the ratio fell to 0.6 as negotiable CDs fell to $\$ 132,340$ million, and C\&I loans increased to $\$ 216,860$ million.

This period is examined because it represents the data avalable since the advent of numerous deregulation measures. One such change is the reserve requirement for different banks on large CDs. To ensure compatibility, only the period since late 1980 is used. In addition, Goldberg has examined the period from 1975 to 1980 and found similar results.

The prime rate used is the average of daily rates reported by five of the nation's ten largest banks (by size of deposits, as of Decenber 31,1980 ). The monthly average includes all calendar days; rates for weekends and holidays are same as the preceding business day.

The CD rate is the secondary market rate, monthly iverage of daily rates, excluding weekends and holidays. The daly rate is an average of the rates offered by five or more lealers. The solnce is table 1.35, in any Federal Reserve Bulletin.

The federal funds rate used is a monthly average of daily rates; the rate for weekends and holiditys is the preceding business day's rate. The daily rate is determined by averaging the rates from approximately six brokers in the federal funds market reporting to the New York Federal Reserve Bank's trading desk. The individial rates are "weighted" by the volume of transactions and therefore, amount to the "effective" rate. the prime rate level relative to other market rates. To do this, the following equation was estimated:

(1) $\mathrm{PR}_{\mathrm{t}}=\alpha_{0}+\sum_{\mathrm{i}=0}^{\mathrm{N}} \beta_{\mathrm{i}} \mathrm{i}_{\mathrm{t}-\mathrm{i}}+\epsilon_{\mathrm{t}}$

where $P R_{t}$ represents the prime rate, $i_{t-i}$ stands for contemporaneous and lagged values of the $\mathrm{CD}$ rate or the federal funds rate, and $\epsilon_{\mathrm{t}}$ is a random error term. The lags are included to reflect the pattern observed in chart $1 .^{6}$

Table 1 reports the results from estimating equation lover the period September 1980 to December $1982^{7}$ As hypothesized, movements in the prime rate are explained reliably by both the CD rate and the federal funds rate as proxies for the bank's cost of loanable funds. ${ }^{8}$ Each regression outcome suggests that the prime rate reflects not only the marginal cost of acquiring additional funds (represented by the contemporaneous term), but also the cost of managing existing liabilities. ${ }^{9}$

Another interesting aspect of the results in table 1 is the different long-run effects. For example, a 100 basis-point change in the $C D$ rate results in a 106

\footnotetext{
A simblar equation is estimated in Goldberg, "The Pricing of the Prime." In that study, however, only the CD rate is used.

"The lag length was selected to minimize the standard error of the equation. In each case, adding another lag did not improve the fit significantly.
}

The Durbin-Watson statistic for the equation using the $\mathrm{CD}$ rate fals in the indeteminate range. Applying a first-order antocorrelation correction procedure yielded an estimated value of tho that was not statisticaly different from zero at the 5 percent level. Consecuently, the OLS results presented in table 1 are used in the analysis.

An alternative equation was estimated using the 4-month commercial paper rate to explain movenents in the prime rate. This rate was used because it represents an altemative source of funds for firms and, therefore, a competitive rate vis-a-vis the prime rate. The outcome of the estimation is

$$
\begin{aligned}
& \mathrm{PR}_{\mathrm{e}}=0.63+0.628 \mathrm{CPR}_{t}+0.401 \quad \mathrm{CPR}_{\mathrm{t}-\mathrm{z}}+0.184 \mathrm{CPR}_{-2} \\
& \overline{\mathrm{R}}^{2}=0.98 \% \quad S \mathrm{E}=0.334 \quad \mathrm{DW}=1.83 \quad \dot{\mathrm{p}}=0.33
\end{aligned}
$$

where $\rho$ is the frrst-order serial correlation coefficient. The results are quite similar to those preserted in table 1 .

"Goldberg, "The Pricing of the Prime," points ont that this indicates that banks engage in average-cost pricing. In other words, "banks price their prime rate on the basis of some average of their currently - and previously - issued, but still outstanding, costs of managed liabilities" (p. 292).

As noted by Goldberg, the estimated constant term $\left\langle\hat{\alpha}_{i j}\right\}$ represents the bank's profit margin. Note that the constant term is significantly different from zero for both of the equations reported in table 1 but is not in the equation using the commercial paper rate $(\mathrm{fn} .7)$. 
Chart 1

The Prime Rate, 90-Day CD Rate and Federal Funds Rate

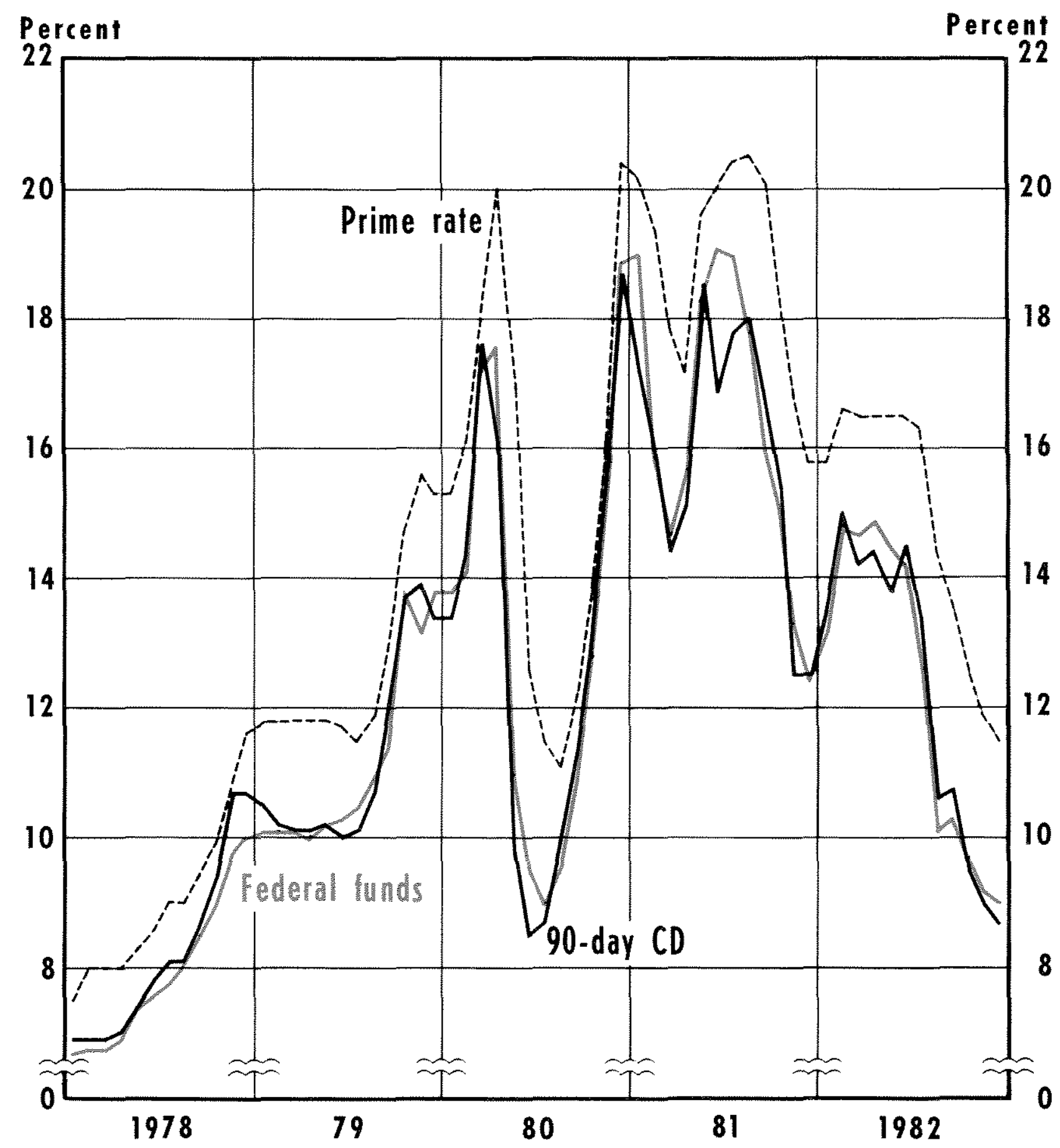


Table 1

Regression Estimates of the Prime Rate: September 1980 to December 1982

\begin{tabular}{|c|c|c|c|c|c|c|c|}
\hline \multirow[b]{2}{*}{ Rate } & \multicolumn{5}{|c|}{ estinated coeflicients? } & \multicolumn{2}{|c|}{$\begin{array}{l}\text { Sumnary } \\
\text { statisties? }\end{array}$} \\
\hline & $a_{0}$ & So. & 0. & $40_{2}$ & 20 & $\mathrm{P} P S E$ & ow \\
\hline 90 & $\begin{array}{l}1.58 \\
(3994)\end{array}$ & $(11,63)$ & 9.338 & $\begin{array}{l}0.64 \\
(3.37)\end{array}$ & $\begin{array}{l}1.064 \\
(38.32)\end{array}$ & 0.983 & 144 \\
\hline e & $(5,80$ & $(0.542$ & $\begin{array}{l}0,181 \\
(1,39)\end{array}$ & $(0,243$ & $(27356)$ & $\begin{array}{l}0970 \\
0487\end{array}$ & 173 \\
\hline
\end{tabular}

CD is lie 90.6ay $0 \mathrm{~b}$ rate and $\mathrm{F}$ is he rederal tunds rate

1. stalisics aopear n parentheses.

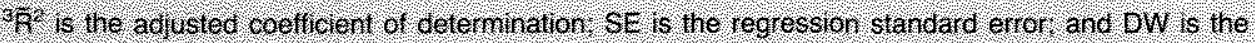
Dutinin Watson statsic

basis-point change in the prime after three months. ${ }^{10} \mathrm{~A}$ similar change in the federal funds rate produces a 97 basis-point change in the prime, a change that is not significantly different from 100 basis points. Note, however, that these changes occur over a three-month horizon; about 55 percent of the effect on the prime rate occurs simultaneously with changes in the CD and federal funds rates.

This evidence suggests that the prime rate closely reflects the costs faced by banks in acquiring new and in managing existing loanable funds. Moreover, the full effect of a change in the cost of funds on the prime rate is not immediate, but takes place over several months. Consequently, reductions in the $\mathrm{CD}$ and the federal funds rates are unlikely to produce immediate declines of equal magnitude in the prime rate; they will do so only with a lag of about three months. ${ }^{\text {I }}$

\footnotetext{
${ }^{10}$ Goldberg reports that, for the period January 1975 to October 1980, the summed effect of changes in the CD rate on the prime rate is 1.076 . For the period January 1977 to October 1980 , the sum is 1.094 . Thus, our result is consistent with those from earlier periods
}

The summed effect of the CD rate, however, is statistically different from unity $(t=2.31)$. This result is expected given the cost, over-and-above interest, that the bank faces when it issues a new $\mathrm{CD}$. One major cost is the reserves that the bank must hold for each CD issued. Currently, the required resesve ratio is 3 percent. If one calculates the "effective" cost of issuing a $\mathrm{CD}-$ one that incorporates both the interest expense and the opportunity cost incurred by holding non-nterest-bearing reserves against the $\mathrm{CD}$ - a $\mathrm{CD}$ rate of 10 percent then becomes 10.31 percent. Thus, for a 100 basis-point change in the $C D$ rate, the change in the effective cost to the bank actually is 103 basis points. Indeed the summed effect reported in table 1 does not differ from an effective rate of 1.03 . The hypothesis that $\Sigma \beta_{i}=1.03$ canot be rejected at any reasonable level of significance $(t=1.22$ ).

"The effect of average-cost pricing durng periods of rising and falling interest rates has been noted by Goldberg, "The Pricing of
Table 2

Actual and Forecasted Values of the Prime Rate: January 1983 to April 1983

\begin{tabular}{|c|c|c|c|}
\hline \multirow[b]{2}{*}{ Period } & \multirow[b]{2}{*}{ Aclual } & \multicolumn{2}{|c|}{ Forecasted values isine } \\
\hline & & Co & Pf \\
\hline Waruary $198 \%$ & $1 / 16 \%$ & $10.67 \%$ & $11136 \%$ \\
\hline february & 10.98 & 1068 & 1,15 \\
\hline Marth & 10.50 & 1072 & 1120 \\
\hline Apul & 1050 & $107 \%$ & $117 \%$ \\
\hline
\end{tabular}

\section{woreculng the prime hate}

The equations in table 1 were estimated through December 1982 to permit out $\cdots$ of -sample forecasts of the prime rate to be obtained for the first four months of 1983. If recent levels of the prime rate are significantly greater than those forecasted using the regres-

the Prime." For example, he states that "During a period of declining interest rates. . their past-issued, but still outstanding. labilities are more expensive than their currently-issued managed liabilities. This leads to a situation where their average (over time) cost-based formula calls for a prime rate substantialy in excess of the bank's prime customer's cost of commercial paper firancing" (p. 288).

It atso should be noted that evidence exists sugtyesting that banks switch from average-cost pricing to marginal-cost pricing during periods of dechining narket rates. In other words, banks may price discriminate in favor of their best customers by offering "below prime" loans. Because the sample used here is too restric tive to test this hypothesis (the available data is quarterly) the reader is referred to Coldberg (pp. 289-92) for a discussion of and empirical results favoring the "below prime" lending scenario. 
sions reported in table 1 , then recent criticisms may be justified. If not, then the recent behavior of the prime rate simply reflects the underlying relationship between a bank's cost of funds and its lending rate captured in equation 1.

The prime rate forecasts based on the equations in table 1 and the actual prime rate for January through April 1983 are shown in table 2. During January, the actual prime rate exceeded the rate forecasted with the $C D$ rate by about 50 basis points. In contrast, the prime rate was 20 basis points less than the one forecasted using the federal funds rate. In each instance, however, the forecast errors were not unusually large for the estimated equation; they were within two standard errors of the regression standard errors.

The lagged effect of the recent changes in the cost of funds (see chart 1) on the prime become more apparent in February, March and April. During February, for example, the average forecast error falls to 26 basis points. By March and April, however, the predicted prime rate exceeds the actual rate by an average of 46 basis points and 77 basis points, respectively. Given recent movements in the cost of funds, the results in table 2 indicate that the prime rate has not been too high relative to other market rates during the past few months.

\section{CONOUNOM}

Have banks kept the prime rate "too high?" The evidence presented in this article suggests that, rela tive to their cost of funds, banks have not kept the prime rate unduly high during the past few months. The prime rate adjusts, with a lag, to changes in the cost of acquiring and managing loanable funds. These costs are represented here by the 90 -day CD rate and the federal funds rate. The well-established empirical relationship between the prime rate and these measures explains why the prime rate has not decreased as fast as these other rates during early 1983.

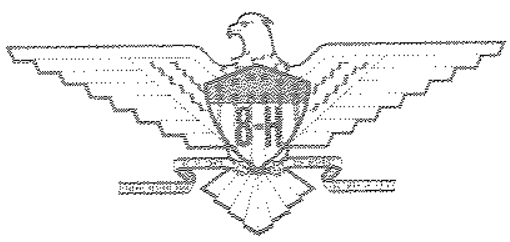

